\title{
Primary renal renin secretion responding to angiotensin converting enzyme inhibition
}

\author{
P.G. Newrick, N. Millar, M. Penney ${ }^{1}$ and R.J.M. Corrall \\ Department of Medicine, Bristol Royal Infirmary, Bristol BS2 $8 \mathrm{HW}$ and ${ }^{1}$ Department of Chemical \\ Pathology, Royal Gwent Hospital, Newport NP9 2UB, UK
}

Summary: A case of primary renal renin secretion of probable neoplastic origin is reported. Investigation demonstrated renin secretion to be incompletely autonomous with suboptimal suppression to posture and hypervolaemia. Easy control of the hypertension and hypokalaemia was achieved with an angiotensin converting enzyme inhibitor. Such treatment may prove to be a preferable option to surgery.

\section{Introduction}

Primary overproduction of renin is a rare cause of hypertension. We report a case of renal renin secretion of probable neoplastic origin that is controlled with angiotensin converting enzyme inhibition, a treatment not previously described for this condition.

\section{Case report}

A 56 year old white female on no medication presented with supraventricular tachycardia and ischaemic chest pain. Her potassium was found to be low at $2.3 \mathrm{mmol} / \mathrm{l}$ and following an infusion of potassium the arrhythmia reverted with cardioversion. On recovery blood pressure was found to be $178 / 110 \mathrm{mmHg}$ lying and $150 / 110 \mathrm{mmHg}$ standing. Despite persistent hypokalaemia urinary potassium excretion was in the range of $70-120 \mathrm{mmol} /$ 24 hours. Other serum electrolytes $(\mathrm{mmol} / \mathrm{l})$ were as follows: sodium 138 , bicarbonate 30 , chloride 95 , urea 5.5 The following were normal or negative: creatinine $(77 \mu \mathrm{mol} / \mathrm{l})$, creatinine clearance $(97 \mathrm{ml} /$ $\min$ ), urinary $\mathrm{pH}$ and osmolality, calcium, liver and thyroid function tests, random cortisol, urinary catecholamines, glucose, chest X-ray and repeated urinary diuretic and purgative screens. Excretion urography, adrenal and renal ultrasound and enhanced renal computed tomography (CT) were normal. Detailed selective renal arteriography including oblique views was entirely normal with no suggestion of segmental branch stenosis. Renal

Correspondence: P.G. Newrick, M.D., M.R.C.P., Department of Medicine, Bristol Royal Infirmary, Bristol BS2 8HW, UK.

Accepted: 5 February 1992 vein catheterization showed a disproportionately high level in renin activity of $>60 \mathrm{ng} / \mathrm{ml} / \mathrm{h}$ from the right renal vein. All other sites sampled (including left renal vein, femoral veins and from below and above both renal veins) were in the range $18-21 \mathrm{ng} / \mathrm{ml} / \mathrm{h}$. Renal magnetic resonance imaging (MRI) showed an equivocal abnormality in the right kidney.

Further renin and aldosterone studies were undertaken and measurements also made during whole body head-out immersion to induce central hypervolaemia (Table I). Twenty-four hour urinary sodium excretion was 51 and $72 \mathrm{mmol}$ on the days of the basal and immersion studies, respectively. The basal measurements demonstrated an exaggerated rise in renin on assumption of the upright posture. Compared with previous immersion studies in our laboratory ${ }^{1,2}$ our patient had a low basal excretion of sodium with a relatively normal increase in natriuresis but a clearly suboptimal inhibition of renin secretion indicating a relative insensitivity to the effect of central hypervolaemia. Our patient refused surgical exploration and after initial treatment with captopril $25 \mathrm{mg}$ twice daily she has been maintained on enalapril $5 \mathrm{mg}$ daily and blood pressure readings are consistently around $130 / 80 \mathrm{mmHg}$ with serum potassium in the range 4-4.5 $\mathrm{mmol} / \mathrm{l}$. Three years later she remains asymptomatic and repeat MRI of the kidneys is unchanged.

\section{Discussion}

The present patient presented with an arrhythmia secondary to hypokalaemia and was found to be hypertensive. Subsequent investigation demonstrated high renin and aldosterone levels. This 
Table I Peripheral renin, aldosterone and ANP measurements in patient with primary renal renin secretion

\begin{tabular}{llllc}
\hline & $\begin{array}{c}\text { Renin } \\
(\mathrm{ng} / \mathrm{ml} / \mathrm{h})\end{array}$ & $\begin{array}{c}\text { Aldosterone } \\
(\mathrm{pmol} / \mathrm{l})\end{array}$ & $\begin{array}{c}\text { ANP } \\
(\mathrm{pg} / \mathrm{ml})\end{array}$ & $\begin{array}{c}U_{\mathrm{Na}} \\
(\mu \mathrm{mol} / \mathrm{min})\end{array}$ \\
\hline $\begin{array}{l}\text { Basal study } \\
\quad \text { Supine }\end{array}$ & $18(<6)$ & $1487(70-350)$ & & \\
$\quad$ Upright & $48(<11)$ & $1817(150-750)$ & & \\
$\begin{array}{l}\text { Immersion study } \\
\text { Basal (sitting) }\end{array}$ & & & & \\
$\quad$ at 30 min \\
$\quad$ at 60 min & 9 & 1836 & 34.3 & \\
$\quad \begin{array}{l}\text { Immersed } \\
\quad \text { at 60 min }\end{array}$ & 7.5 & 1770 & 31 & 1.1 \\
$\quad$ at 120 min & 6.6 & 648 & 78.3 & 13.8 \\
& & & 75.8 & 16.5 \\
\hline
\end{tabular}

Normal range is given in parentheses. $\mathrm{ANP}=$ atrial natriuretic peptide;

$U_{\mathrm{Na}}=$ urinary sodium excretion.

syndrome is seen in renovascular disease, accelerated hypertension, oestrogen therapy and in a rare group of conditions in which there is primary overproduction of renin. Such conditions include oat cell carcinoma of the lung, renal cell carcinoma and Wilms tumour, liver and renal hamartomas and renal haemagiopericytoma. In our patient renovascular disease was excluded by arteriography, and the absence of retinopathy, cardiomegaly, raised creatinine or marked diastolic hypertension effectively rules out accelerated hypertension as an explanation. The patient was not taking oestrogens and severe hypokalaemia is not a feature in such cases. Other conditions with high renin and aldosterone levels such as saltwasting syndromes, oedematous states and Bartter's syndrome have different clinical presentations and are not characterized by the presence of hypertension. We therefore consider the most likely diagnosis, despite failure to image a tumour with certainty, is that of a renal renin-secreting tumour or haemangiopericytoma.

The first case of primary reninism with hypertension secondary to this rare tumour was described by Robertson et $a .^{3}$ who gave his name to the syndrome and approximately 20 cases have been described in the literature to date. These juxtaglomerular cell tumours tend to be $2-3 \mathrm{~cm}$ in diameter and occur in a subcapsular position. A tendency to malignant transformation or local recurrence after excision has not been recorded. In only three-quarters of reported cases has the tumour been imaged prior to operation. Renal arteriography and enhanced CT scanning have been most useful techniques. ${ }^{4}$ In at least five cases (including Robertson's own) the tumour was not imaged by any technique (although there are no other reports of the use of MRI) and, following nephrectomy, it has been found to be as small as $2 \mathrm{~mm}$ in diameter. ${ }^{5}$

Renin secretion appears to be autonomous in about half the cases, as judged by the absence of response to posture or saline loading. In this present case absolute levels of renin remained high although secretion was not completely autonomous but responded suboptimally to posture and immersion (falling by approximately $35 \%$ compared with the normal expected suppression of $60-70 \%$ ). Despite inappropriately high renin and aldosterone levels natriuresis occurred during immersion possibly mediated in part via atrial natriuretic peptide, levels of which increased normally during immersion.

The present case demonstrates the easy control of hypertension and hypokalaemia with the use of angiotensin converting enzyme inhibition. This appears to provide an effective alternative to surgery and may prove the preferred option in some cases even when exact anatomical localization has been achieved.

\section{References}

1. O' Hare, J.P., Roland, J.M., Walters, G. \& Corrall, R.J.M. Impaired sodium excretion in response to volume expansion induced by water immersion in insulin-dependent diabetes mellitus. Clin Sci 1986, 71: 403-409.
2. Anderson, J.V., Millar, N.D., O'Hare, J.P., Mackenzie, J.C., Corrall, R.J.M. \& Bloom, S.R. Atrial natriuretic peptide: physiological release associated with natriuresis during water immersion in man. Clin Sci 1986, 71: 319-322. 
3. Robertson, P.W., Klidjian, A., Harding, L.K., Walters, G., Lee, M.R. \& Robb-Smith, A.H.T. Hypertension due to a renin-secreting renal tumour. Am J Med 1967, 43: 963-976.

4. Dunnick, N.R., Hartman, D.S., Ford, K.K., Davis, C.J. \& Amis, E.S. The radiology of juxta-glomerular tumours. Radiology 1983, 147: 321-326.
5. Hirose, M., Arakawa, K., Kikuchi, M. et al. Primary reninism with renal hamartomatous alteration. JAMA 1974, 230: $1288-1292$. 